\title{
Shariah Compliant Hotel Deployment: Unveiling A Case within the Hotel Industry in Malaysia
}

Noor Sufiawati Khairani, Noriah Ismail, Emelin Abdul Wahid, Mohamad Zaki Razaly, Noraizah Abu Bakar

To Link this Article: http://dx.doi.org/10.6007/IJARBSS/v11-i12/11378 DOI:10.6007/IJARBSS/v11-i12/11378

Received: 09 October 2021, Revised: 13 November 2021, Accepted: 27 November 2021

Published Online: 16 December 2021

In-Text Citation: (Khairani et al., 2021)

To Cite this Article: Khairani, N. S., Ismail, N., Wahid, E. A., Razaly, M. Z., \& Bakar, N. A. (2021). Shariah Compliant Hotel Deployment: Unveiling A Case Within the Hotel Industry in Malaysia. International Journal of Academic Research in Business and Social Sciences, 11(12), 1616-1640.

Copyright: (c) 2021 The Author(s)

Published by Human Resource Management Academic Research Society (www.hrmars.com)

This article is published under the Creative Commons Attribution (CC BY 4.0) license. Anyone may reproduce, distribute, translate and create derivative works of this article (for both commercial and non0-commercial purposes), subject to full attribution to the original publication and authors. The full terms of this license may be seen

at: http://creativecommons.org/licences/by/4.0/legalcode

Vol. 11, No. 12, 2021, Pg. $1616-1640$

http://hrmars.com/index.php/pages/detail/IJARBSS

JOURNAL HOMEPAGE

Full Terms \& Conditions of access and use can be found at http://hrmars.com/index.php/pages/detail/publication-ethics 


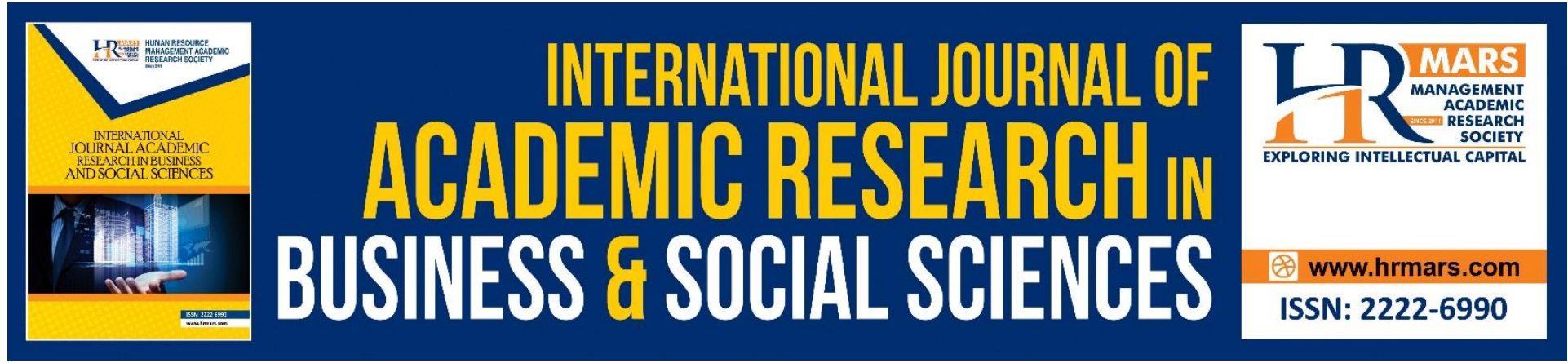

\title{
Shariah Compliant Hotel Deployment: Unveiling A Case within the Hotel Industry in Malaysia
}

\author{
Noor Sufiawati Khairani \\ Faculty of Accountancy, Universiti Teknologi MARA (UiTM) Johor Segamat Campus, 85000 \\ Johor, Malaysia \\ Email: noors771@uitm.edu.my
}

\begin{abstract}
Noriah Ismail
Academy of Language Studies, Universiti Teknologi MARA (UiTM) Johor Segamat Campus, 85000 Johor, Malaysia

Email: noriah135@uitm.edu.my
\end{abstract}

\section{Emelin Abdul Wahid}

Faculty of Accountancy, Universiti Teknologi MARA (UiTM) Johor Segamat Campus, 85000 Johor, Malaysia

Email: emeli459@uitm.edu.my

\section{Mohamad Zaki Razaly}

Academy of Contemporary Islamic Studies, Universiti Teknologi MARA (UiTM) Johor

Segamat Campus, 85000 Johor, Malaysia

Email: moham694@uitm.edu.my

\section{Noraizah Abu Bakar}

Faculty of Accountancy, Universiti Teknologi MARA (UiTM) Johor Segamat Campus, 85000 Johor, Malaysia

Email: norai738@uitm.edu.my

\begin{abstract}
This study examines the deployment of Shariah Compliant Hotel $[\mathrm{SCH}]$ in the Malaysian hotel industry. Proponents of SCH suggest that Shariah compliant accommodation for tourists is an important strategy deployed for competitive advantage in the Islamic hospitality sector. However, little is understood about the deployment of $\mathrm{SCH}$ within the Malaysian hotel industry. The present study addresses this literature gap by focusing on both the SCH deployment practices and key business considerations of the organisational Shariah governance within the Malaysian hotel industry. The study adopts a qualitative research methodology, with data collected through semi-structured interviews and document reviews from a single Shariah Compliant case hotel operating in Malaysia. Consistent with the
\end{abstract}


literature, our findings suggest that the case hotel uses a holistic, process approach to deploy $\mathrm{SCH}$ practices. This structured, regulated $\mathrm{SCH}$ deployment approach involves several key business considerations of organisational Shariah governance that directly supports $\mathrm{SCH}$ practices encompassing the financial management, operations, interior and design as well as the services and facilities offered to customers of the hotel.

Keywords: Shariah Compliant Hotel, Shariah Compliant Hotel Deployment Practices, Organizational Shariah Governance, Hotel Industry, Malaysia

\section{Introduction}

Islamic tourism which represents the largest and most lucrative untapped niche market in global tourism, is one of the attractive segments in tourism industry world-wide (Abu Karim et al., 2017; El-Gohary, 2015). Hoteliers in Malaysia thus have attempted innovative initiatives to offer hotel facilities in accordance with the religious beliefs of the Muslim tourists (Salleh et al., 2014). In recent years, Shariah compliant have been identified as an added competitive advantage among hotels in the country especially in attracting both local and foreign Muslim tourists. This is in line with the Malaysian government's goal in establishing the country as a global Halal hub for halal products and services. As a move forward, the food and halal hub are among the fifteen key economic growth activities (KEGA) identified in the nation's Shared Prosperity Vision 2030. Within the Islamic hospitality sector, to date, several halal guidelines such as MS2610:2015, MS1900:2014, and MS1500:2009 by Malaysian Standards are available. For instance, MS2610:2015 Muslim friendly hospitality services - Requirements is released in 2015. It is a documented standard focusing on Shariah-guided requirements for tourism industry players in assuring and preserving the integrity of products and services provided for Muslim travellers (Department of Standards Malaysia, 2015). Meanwhile the MS1900:2014 Shariah-based quality management systems - Requirements with guidance (formerly MS1900:2005) was first launched in 2005. It is a structured system to warrant organisations and are managed in compliance with the principles of Shariah and practice of the quality management system in delivering products and services that meet customer requirements (Department of Standards Malaysia, 2014; Mohamad Ali et al., 2016). Recently in 2019, the government of Malaysia has introduced the "Muslim-Friendly Accommodation Recognition" [MFAR] initiative, a form of accreditation implemented by the Islamic Tourist Centre [ITC] which recognises Shariah compliant accommodation for tourists (The Star, 2019).

The current Covid-19 pandemic scenario has tremendously impacted the tourism industry world-wide, including within the local scenario (Vasantha, 2021; El-Gohary, 2020). However, as the number of foreign tourists is currently diminishing, the Malaysian tourism industry turns to the domestic market. Hotel operators and owners are coming up with innovative packages to meet the needs and budget of domestic travellers (Hoong, 2021). With approximately 60 percent of the country's 28 million current population are Muslims (Islamic Tourism Centre, 2021), SCH may proves a good sustainability strategy among hotels in Malaysia.

Past studies have found that hoteliers have yet to holistically abide and equip themselves with the requirements as Shariah Compliant Hotel $[\mathrm{SCH}$. Proponents of $\mathrm{SCH}$ (Abd Razak et al., 2019; Abu Karim et al., 2017) suggest the need to understand the comprehensive Shariah compliant [SC] deployment practices as well as the key business considerations that reflect the organisational Shariah governance for the deployment of $\mathrm{SCH}$ to promote $\mathrm{SCH}$. This far, 
extensive studies investigating a comprehensive view of a shariah compliant hotel's operation is still lacking within the Malaysian context. Whilst the government's support for $\mathrm{SCH}$ is strong, there is no specific identification of the comprehensive $\mathrm{SCH}$ deployment practices and the key elements of the organisational Shariah governance that clearly models SCH in Malaysia. Furthermore, the adoption of the regulated procedures as well as the participation in the accreditation are voluntarily in nature. For instance, the MS 2610:2015 which particularly targets the accommodation premises, tour packages and tourist guides only provides a general requirement of which its implementation is on a voluntary basis (Amer Nordin \& Abd Rahman, 2018). As a result, many hotels in Malaysia may have embarked on implementing piecemeal SCH initiatives, with limited understanding of the key elements needed for its longterm success. Therefore, gaining insights about the deployment of $\mathrm{SCH}$ in a SCH hotel within the Malaysian hotel industry may provide an interesting start to build a roadmap for Islamic tourism sustainability within the local context.

This paper thus contributes to generate insights into the deployment of $\mathrm{SCH}$ within the Malaysian hotel industry context. Specifically, this research aims to address the following research questions:

1. What $\mathrm{SCH}$ practices are deployed by the selected case hotel?

2. What business considerations reflect the execution of organisational Shariah governance for the deployment of $\mathrm{SCH}$ at the selected case hotel?

\section{Literature Review \\ Malaysia's Tourism Industry}

The tourism industry represents the nation's third-largest revenue contributor (Vasantha, 2021). Mohd Yusof and Muhammad (2013) earlier highlighted that the tourism industry is one of the major industries which provides foreign exchange earnings to the country and offers employment to the people. Realising these potentials, the government of Malaysia had earlier strategized under the Economic Transformation Programme to make the country a global leading tourist destination (Vasantha, 2021). Vasantha (2021) further added that this is to meet the nation's anticipation of increasing numbers of tourist arrivals and foreign receipts from year to year. However, due to the unprecedented effects and by virtue of the scale caused by the Covid-19 pandemic, similar to other countries such as neighbouring ASEAN countries including Thailand, Singapore, Vietnam and Indonesia, Malaysia is experiencing a decline of its tourism performance (Tourism Malaysia, 2020). As depicted in Table 1, Malaysia's tourism performance records a drastic plunge from January to September 2020 (Tourism Malaysia, 2020).

Table 1: Malaysia's Tourism performance Jan. - Sept. 2019 \& 2020 (source: Tourism Malaysia, 2020)

\begin{tabular}{|l|l|l|}
\hline & \multicolumn{1}{|c|}{ Jan.-Sept.2019 } & \multicolumn{1}{|c|}{ Jan.-Sept.2020 } \\
\hline Tourist arrivals (million) & 20.10 & 4.29 (decline: $78.6 \%)$ \\
\hline Receipts (RM billion) & 66.10 & 12.60 (decline: $80.9 \%)$ \\
\hline Per capita expenditure (RM) & $3,289.30$ & $\begin{array}{l}2,938.40 \quad \text { (decline: } \\
10.70 \%)\end{array}$ \\
\hline $\begin{array}{l}\text { Excursionists/Daily visitors to Malaysia } \\
\text { (million) }\end{array}$ & 6.91 & 1.73 (decline: $74.9 \%)$ \\
\hline
\end{tabular}


Table 1 shows that tourist arrivals to Malaysia shrunk by $78.6 \%$ from 20.1 million in the first nine months of 2019 to 4.29 million in the corresponding period during 2020. The tourism receipts thus reduced by $80.9 \%$ from RM66.1 billion during the first nine months of 2019 to RM12.6 billion in the corresponding period during 2020. In addition, Table 1 also depicts the statistics for daily visitors which fell $74.9 \%$ from 6.91 million to 1.73 million in the JanuarySeptember period. Along this line of discussion, the hotel industry alone loses approximately RM6.54 billion in revenue during 2020 (Vasantha, 2021).

With the drastic decline of international travellers to Malaysia, the local tourism industry is now focusing on the domestic market as lifeline and the solution for the industry to recover (Hoong, 2021; Bernama, 2021; Shankar, 2021). Bernama (2021) for instance, reported that Malaysia recorded the largest increment in the domestic tourism market among ASEAN countries when lockdowns were lifted in the second half of 2020. An online survey conducted on domestic travel in Malaysia from 7 April till 13 April 2020 among others indicated that $96 \%$ of the respondents intend to travel domestically (Tourism Malaysia, 2020). Consistent with this finding, the recent Airbnb Malaysia's Travel Trends Survey 2021 highlighted that domestic tourism have gradually improved during the Recovery Movement Control Order (RMCO) in 2020 as many local travellers started travelling locally after being confined at home and prohibited from international travels (Hoong, 2021). In addition, Hoong (2021) highlighted that the findings of the survey indicated hoteliers are offering innovative packages to suit the needs and budget of domestic travellers. Being Islam as the country's official religion and majority population are Muslim, Shariah Compliant Hotel (SCH) thus posed as a potential strategy for sustainability of the business.

Within the Islamic tourism perspective - one of the attractive segments in tourism industry world-wide (Abu Karim et al., 2017; El-Gohary, 2015), Malaysia was recognised as world's top preferred destination for Muslim travellers. For instance, the nation was named one of the favourite destinations among Muslim travellers world-wide, alongside Turkey and the United Arab Emirates (UAE) during the 2013 International Tourism Bourse [ITB] in Berlin (Islamic Tourism Centre, 2021). Similarly, a survey made by CrescentRating, a Singapore-based Muslim travel consultancy showed that Malaysia was rated the world's top Muslim-friendly destination leaving Saudi Arabia, United Arab Emirates, Egypt and Turkey behind. Recently, Malaysia ranked first in the Mastercard-CrescentRating Global Muslim Travel index 2021 (Islamic Tourism Centre, 2021). Hence, leveraging on this advantage, Malaysia should be at the forefront in introducing $\mathrm{SCH}$ concept.

\section{Shariah Compliant Hotel (SCH) Concept and Practices}

Tourism, Arts and Culture Minister Datuk Seri Nancy Shukri reported that in 2020, a total of 42 hotels are being recognised as shariah compliant under the Islamic Tourism Centre (ITC)'s Muslim-Friendly Accommodation Recognition [MFAR] scheme (Teh Athira, 2020). This is an increase by 30 hotels in 2020, compared to 12 hotels in 2019. The Tourism, Arts and Culture Minister further added that the increasing number of MFAR labelled hotels is to attract more Muslim tourists and thus strengthen the country's tourism industry (Teh Athira, 2020). Extant literature (eg., Che Omar \& Mohamad Ali Adaha, 2019; Md Salleh et al., 2014; Sahida et al., 2011) suggested that in recent years, Shariah compliant is recognised as an added competitive advantage among hotels in attracting both domestic and foreign Muslim tourists. With 
regards to the hotel industry in Malaysia, $\mathrm{SCH}$ thus has the potential as a competitive business strategy for sustainability.

Despite its potentials, the concept of SCH is relatively new (Musa et al., 2017). SCH is defined as a hotel establishment that provides services, facilities, financial and operations in accordance to Shariah principle (Che Omar \& Mohamad Ali Adaha, 2019; Abu Karim et al., 2017). Muhammad (2009) earlier defined SCH as hotels of which products, services offered, and financial transactions fully obeying the Syariah principles, from serving halal food and beverages to implement all parameters of Islamic values for health, safety, environment, and the benefits on economics to all mankind regardless of race, faith, or culture. Along this line of discussion, Che Ahmat et al. (2015) highlighted that SCH is about strictly complying with the Islamic principles holistically, not merely on the operational side which includes the products and services offered to the customers, but also include from the initial stage of designing the hotel as well as the financial transactions. Meanwhile Abd Razak et al. (2019) defined $\mathrm{SCH}$ as a hotel that meets the needs of Muslim tourists based on the Shariah law where the hotel normally uses certain standards or laws to certify the requirements provided to achieve Shariah compliance. Drawing from these definitions in the extant literature, a more comprehensive definition is put forward in this study. Shariah Compliant Hotel [SCH] thus may be defined as a hotel that holistically comply to the Shariah principles encompassing the hotel financial management, operations, interior and design as well as the services and facilities provided in meeting the needs of its customers and adopted certain standards or laws to certify its Shariah compliance.

Even though Malaysia is recognised as a progressive Islamic country - an ideal country to be at the forefront in introducing SCH concept, extant studies (eg., Abd Razak et al., 2019; Abu Karim et al., 2017; Md Salleh et al., 2014; Mohd Yusof and Muhammad, 2013) indicated that the concept is yet to be explored and necessitated further investigation. Abu Karim et al. (2017) for instance, claims that hotel operators are unclear with the right SCH practices. Md Salleh et al. (2014) had earlier pointed out that the SCH practices are not holistically deployed and failing to see the actual needs of the Muslim guests. More recent, Abd Razak et al. (2019) also posited that studies looking from a comprehensive view of a SCH's operation within the Malaysian hotel industry scenario are still limited. Table 2 depicts the SCH practices and initiatives highlighted in the extant literature. 
Table 2: Shariah Compliant Hotel (SCH) Practices and Initiatives

\begin{tabular}{|c|c|c|c|c|c|c|c|c|c|}
\hline \multirow[b]{2}{*}{$\begin{array}{c}\mathrm{SCH} \\
\text { Practices }\end{array}$} & \multirow[b]{2}{*}{ SCH Initiatives } & \multicolumn{8}{|c|}{ Extant Literature } \\
\hline & & $\begin{array}{l}\frac{m}{1} \\
\text { مे } \\
\frac{0}{0} \\
\frac{0}{2} \\
\text { N } \\
\text { N } \\
\text { O }\end{array}$ & 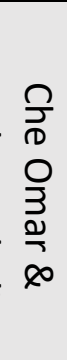 & 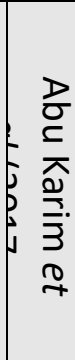 & 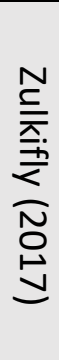 & 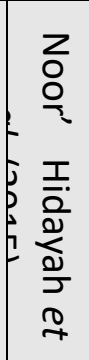 &  & 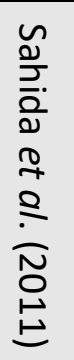 & 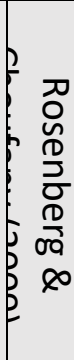 \\
\hline \multirow[t]{2}{*}{$\begin{array}{l}\mathrm{SCH} \\
\text { Financial }\end{array}$} & $\begin{array}{l}\text { Islamic financed management with follow } \\
\text { zakat principles }\end{array}$ & $\mathrm{V}$ & & $\sqrt{ }$ & & & & & $\sqrt{ }$ \\
\hline & $\begin{array}{l}\text { Islamic funding (hotel financed through } \\
\text { Islamic financial instruments) }\end{array}$ & $\mathrm{V}$ & & & $\mathrm{V}$ & & $\sqrt{ }$ & & $\sqrt{ }$ \\
\hline \multirow{18}{*}{$\begin{array}{l}\text { SCH } \\
\text { Design \& } \\
\text { Interior }\end{array}$} & Single women floor & & & $\sqrt{ }$ & $\mathrm{V}$ & $\sqrt{ }$ & $\sqrt{ }$ & & $\sqrt{ }$ \\
\hline & Single male floor & & & $\sqrt{ }$ & & $\sqrt{ }$ & $\sqrt{ }$ & & $\sqrt{ }$ \\
\hline & Islamic floor for Muslim (family) travellers & & & & $\mathrm{V}$ & $\sqrt{ }$ & & $\sqrt{ }$ & \\
\hline & $\begin{array}{l}\text { Public area decorations should not depict } \\
\text { the human \& animal form }\end{array}$ & $\mathrm{V}$ & $\mathrm{V}$ & $\sqrt{ }$ & $\mathrm{V}$ & $\mathrm{V}$ & $\mathrm{V}$ & & $\sqrt{ }$ \\
\hline & $\begin{array}{l}\text { Rooms decoration should not depict } \\
\text { human \& animal form }\end{array}$ & $\sqrt{ }$ & $\mathrm{v}$ & $\sqrt{ }$ & $\mathrm{V}$ & $\sqrt{ }$ & $\sqrt{ }$ & & \\
\hline & $\begin{array}{l}\text { Furnishings should follow according to } \\
\text { Islamic rules \& regulations }\end{array}$ & & & & & $\sqrt{ }$ & & & \\
\hline & $\begin{array}{l}\text { Appearance of Arabesque/calligraphy } \\
\text { arts in the room }\end{array}$ & & $\mathrm{V}$ & & & & & & \\
\hline & $\begin{array}{l}\text { Spacious bedrooms for Muslim guest } \\
\text { perform their prayer }\end{array}$ & & $\mathrm{V}$ & $\mathrm{V}$ & & & & & \\
\hline & Qiblat direction sign & $\mathrm{V}$ & $\mathrm{V}$ & $\sqrt{ }$ & $\mathrm{V}$ & & $\sqrt{ }$ & $\sqrt{ }$ & $\mathrm{V}$ \\
\hline & Bidets in the bathroom & & $\mathrm{V}$ & $\sqrt{ }$ & $\mathrm{V}$ & & $\sqrt{ }$ & $\sqrt{ }$ & \\
\hline & $\begin{array}{l}\text { Bed \& toilet cannot be placed facing the } \\
\text { direction of Makkah }\end{array}$ & $\mathrm{V}$ & $\mathrm{V}$ & $\sqrt{ }$ & $\mathrm{V}$ & $\sqrt{ }$ & $\sqrt{ }$ & & $\sqrt{ }$ \\
\hline & Position of door not facing Qiblat & & $\mathrm{V}$ & & & & & & \\
\hline & $\begin{array}{l}\text { Curtains provide total privacy to } \\
\text { occupants. }\end{array}$ & & $\mathrm{V}$ & & & & & & \\
\hline & Separation of bathroom \& toilet & & $\mathrm{V}$ & & & & & & \\
\hline & $\begin{array}{l}\text { Provision of seats in the room for } \\
\text { recitation }\end{array}$ & & $\mathrm{V}$ & & & & & & \\
\hline & $\begin{array}{l}\text { Separate recreational/wellness facilities } \\
\text { for male \& female (swimming pool for } \\
\text { male, female \& family, spa, gym) }\end{array}$ & $\mathrm{V}$ & & $\mathrm{V}$ & $\mathrm{V}$ & $\sqrt{ }$ & $\mathrm{V}$ & & $\sqrt{ }$ \\
\hline & $\begin{array}{l}\text { Separate prayer room for male \& female } \\
\text { (accompanied with Qiblat sign, Quran, } \\
\text { prayer mats, prayer schedule, prayer veil } \\
\text { \& kain sarung) }\end{array}$ & $\mathrm{V}$ & & $\sqrt{ }$ & & $\sqrt{ }$ & $\sqrt{ }$ & $\sqrt{ }$ & \\
\hline & Prayer room provided at decent location & $\mathrm{V}$ & & & $\mathrm{V}$ & & & & \\
\hline
\end{tabular}


INTERNATIONAL JOURNAL OF ACADEMIC RESEARCH IN BUSINESS AND SOCIAL SCIENCES

Vol. 11, No. 12, 2021, E-ISSN: 2222-6990 @ 2021 HRMARS

\begin{tabular}{|l|l|l|l|l|l|l|l|l|l|}
\hline & $\begin{array}{l}\text { Banquet \& meeting rooms (spacious } \\
\text { function room cater for separate seating } \\
\text { for male \& female) }\end{array}$ & & $v$ & & $v$ & & $v$ & $V$ \\
\hline
\end{tabular}

\begin{tabular}{|c|c|c|c|c|c|c|c|c|c|}
\hline \multirow[b]{2}{*}{$\begin{array}{c}\mathrm{SCH} \\
\text { Practices }\end{array}$} & \multirow[b]{2}{*}{ SCH Initiatives } & \multicolumn{8}{|c|}{ Extant Literature } \\
\hline & & 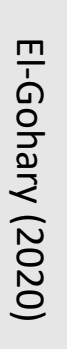 & 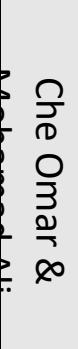 & 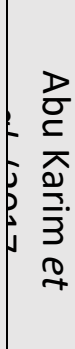 &  & 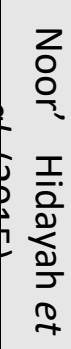 &  & 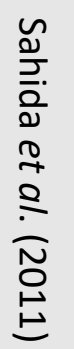 & 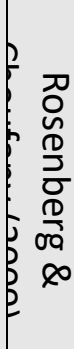 \\
\hline \multirow{18}{*}{$\begin{array}{l}\mathrm{SCH} \\
\text { Operatio } \\
\text { ns }\end{array}$} & Appointed Shariah compliant manager & & & $\sqrt{ }$ & & & & & \\
\hline & $\begin{array}{l}\text { Approval by the Shariah compliant } \\
\text { manager for each event in the hotel }\end{array}$ & & & $\sqrt{ }$ & & & & & \\
\hline & Majority staff are Muslim & $\mathrm{V}$ & & $\sqrt{ }$ & $\mathrm{V}$ & $\sqrt{ }$ & $\mathrm{V}$ & & $\mathrm{V}$ \\
\hline & Akhlaq trained staff & & & $\sqrt{ }$ & & & $\mathrm{V}$ & & \\
\hline & Staff follows Islamic staff dress code & $\mathrm{V}$ & & $\sqrt{ }$ & $\mathrm{V}$ & & $\mathrm{V}$ & $\mathrm{V}$ & \\
\hline & $\begin{array}{l}\text { Guest dress code notice board at the } \\
\text { entrance or lobby }\end{array}$ & $v$ & & $\sqrt{ }$ & $\mathrm{V}$ & & $\sqrt{ }$ & & \\
\hline & $\begin{array}{l}\text { Halal certificate for all food \& beverage } \\
\text { outlets }\end{array}$ & & & $\sqrt{ }$ & & & & $\sqrt{ }$ & \\
\hline & $\begin{array}{l}\text { Halal food only in Halal restaurant \& Halal } \\
\text { room service }\end{array}$ & $\mathrm{V}$ & $\sqrt{ }$ & $\sqrt{ }$ & $\mathrm{V}$ & $\sqrt{ }$ & $\sqrt{ }$ & $\sqrt{ }$ & $\sqrt{ }$ \\
\hline & $\begin{array}{l}\text { Halal lounge (did not selling Haram } \\
\text { beverages) }\end{array}$ & & & $\mathrm{V}$ & $\sqrt{ }$ & & $\sqrt{ }$ & & \\
\hline & No alcohol drinks & $\mathrm{V}$ & & $\sqrt{ }$ & $\mathrm{V}$ & $\sqrt{ }$ & $\mathrm{V}$ & & $\mathrm{V}$ \\
\hline & $\begin{array}{l}\text { Providing sahur \& Ramadhan buffet in } \\
\text { Ramadhan month }\end{array}$ & & & $\sqrt{ }$ & & & & & \\
\hline & $\begin{array}{l}\text { No red-light entertainment (night club \& } \\
\text { disco) }\end{array}$ & $\mathrm{V}$ & & $\sqrt{ }$ & & $\sqrt{ }$ & $\sqrt{ }$ & & $\sqrt{ }$ \\
\hline & Islamic/family entertainment only & $\mathrm{V}$ & & & $\mathrm{V}$ & & & & \\
\hline & $\begin{array}{l}\text { Religious event (Quran \& } \\
\text { recitation, } \\
\text { qiamulail)/Compulsoriin } \\
\text { prayer time. }\end{array}$ & & & $\sqrt{ }$ & & & & $\sqrt{ }$ & \\
\hline & $\begin{array}{l}\text { Ethical promotional activities (absence of } \\
\text { sexual appeal \& manipulation }\end{array}$ & & & $\sqrt{ }$ & & & & & \\
\hline & $\begin{array}{l}\text { Full-time Imam to lead daily prayers \& } \\
\text { Friday prayers }\end{array}$ & & & & & & & $\mathrm{V}$ & \\
\hline & No gambling-related activities & & & & $\mathrm{V}$ & & & & \\
\hline & $\begin{array}{l}\text { Islamic services for conference } \& \text { business } \\
\text { meeting package (eg., doa recital by the } \\
\text { Imam \& provisions of zam-zam water and } \\
\text { dates at the opening of meetings) }\end{array}$ & & & & & & & $\sqrt{ }$ & \\
\hline
\end{tabular}




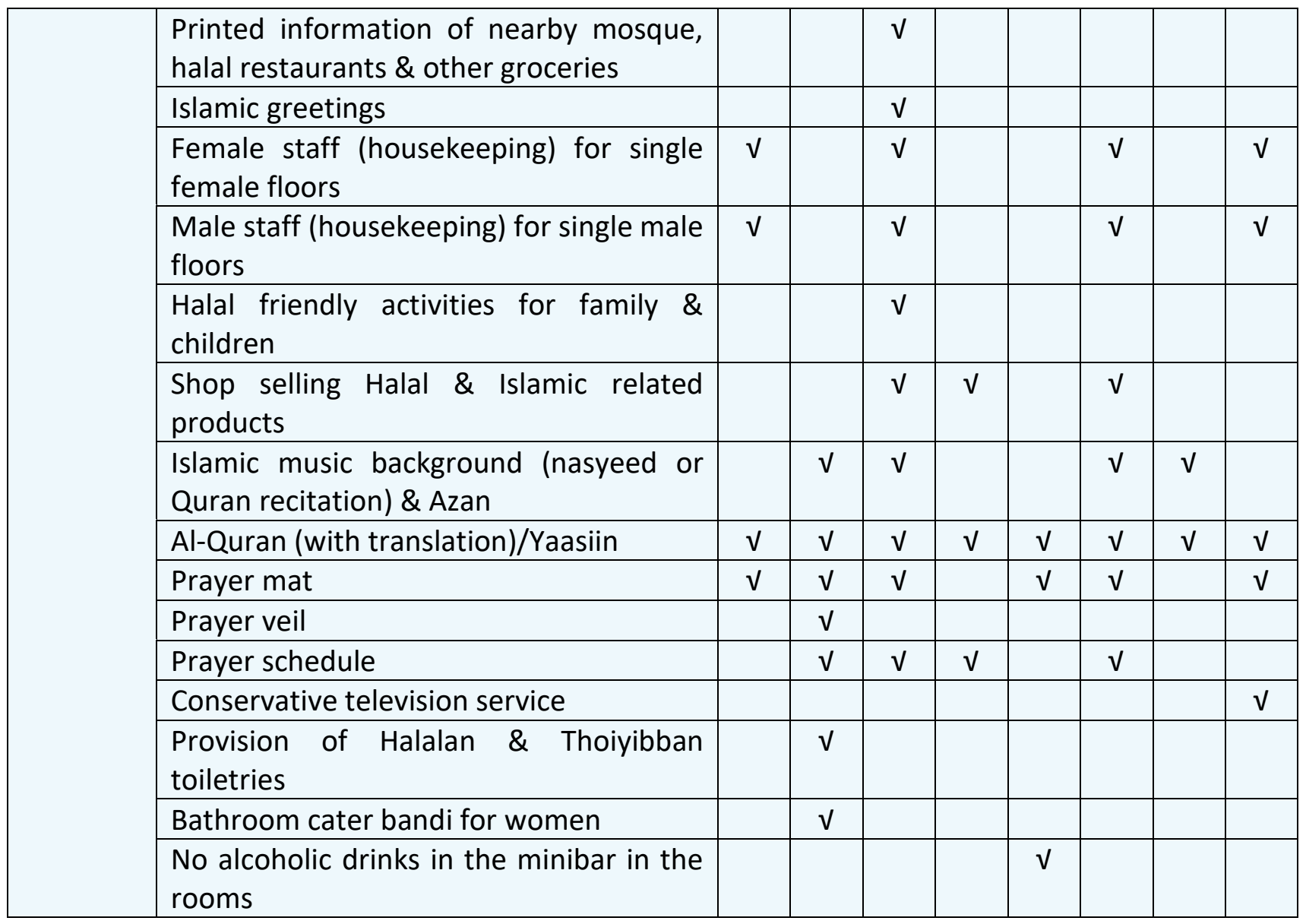

As shown in Table 2, the studies have highlighted three main $\mathrm{SCH}$ practices deployed by $\mathrm{SCH}$ s namely, Islamic Financial Management practice, Islamic Design and Interior practice, and Islamic Operations practice which involves $\mathrm{SCH}$ initiatives on financial management, operations, interior and design as well as the services and facilities. Nevertheless, the initiatives as shown in Table 2 suggested inconsistent and rather piecemeal approach towards the deployment of $\mathrm{SCH}$ practices among hotels to date.

Proponents of SCH (e.g., Samori et al., 2017; and Md Salleh et al., 2014) assert that Shariah compliant hospitality services should not be limited to physical and tangible characteristics only. Abu Karim et al. (2017) in addition suggested that SCH practices should be deployed holistically rather than in unsystematic, piecemeal approach normally related to Muslim Friendly Hotels [MFHs]. Along this line of discussion, Samori et al. (2017) posited that organisational Shariah governance which serves as the backbone of any organisations aiming to run Shariah compliant businesses, has been ignored.

\section{Organisational Shariah Governance}

Within the corporate governance literature, Luo (2005) claims that 'organizational governance' and 'corporate governance' are normally unjustly defined. Luo further defines organisational governance holistically from both a strategic and operational view. According to Luo (2005), organizational governance covers both corporate governance as well as managerial governance. Corporate governance involves the governance and control of corporate affairs while managerial governance emphasises those internal processes and structures that regulate operational decisions and business activities undertaken by the subunits (such as departments and divisions) of a company (Luo, 2005, 
p.3). Luo (2005) further highlighted three common mechanisms for effective corporate governance which are market-based governance, culture-based governance, and disciplinebased governance. However, Luo (2005) commented that the conventional definition normally offers a thin reference of corporate governance by emphasizing that corporate governance framework or system comprises only several market-based governance mechanisms of ownership concentration, board composition, market discipline, board chairmanship, board size, executive compensation, interlocking directorate, and inbreeding. Despite taking a holistic view, Luo's (2005) traditional definition of corporate governance failed to emphasise on the Shariah compliant obligations of Shariah compliant businesses. Therefore, it is noted that prior literature provided only a narrow description of organizational governance that confines solely to corporate governance. Taking the broader perspective, extant governance literature (e.g., Khairani, 2015; Environment Agency, 2004) proposed five business considerations of organisational governance: 1) principle/value; 2) policy; 3) process; 4) performance management system; and, 5) people/oversight.

Principle or values refers to ethical principle, belief or code that guides behaviour (Carnegie Mellon University, 2003). According to Zaphiris (2006), principle or values are defined as a learned set of rules for decision-making which, are apparent in communicated messages and shape attitudes and behaviour (Rokeach, 1973). A comprehensive policy should include a statement of commitment to various contribution themes including values and governance, regulations and control, and business operations that are aligned to the firm's overall business strategy (Environment Agency, 2004). Management systems, initiatives, internal control, monitoring and review, stakeholder dialogue, reporting and verification are among mechanisms for the process considerations. Musa et al. (2017) suggested the need for SCH to follow the standards that in line with global benchmarks such as ISO9000 and Standard Operating Procedures (SOPs). Meanwhile the use of Key Performance Indicators (KPI) is for oversight, implementation, management, and monitoring of the firm's strategy (Environment Agency, 2004) such as SCH. According to Khairani (2015), strong oversight at the board as well as senior management and working levels are considered important. Khairani (2015) further posits that an appropriate organizational governance framework needs to be in place to successfully implement a business strategy.

Within the relatively new concept of $\mathrm{SCH}$ among hotels in the Malaysian scenario, Shariah governance framework is still not clearly visible. Samori et al. (2017) for instance suggested on the adoption of Shariah governance framework of Islamic finance institution industry into the Muslim friendly hospitality industry in Malaysia. Thus, based on the more general governance literature, the findings of this study on the business considerations that reflect the execution of organisational Shariah governance for the deployment of $\mathrm{SCH}$ may offer a starting point in the construction of a Shariah governance framework for $\mathrm{SCH}$ within the hotel industry.

\section{Research Methodology}

With the purpose of acquiring more reliable knowledge and better understanding of events related to $\mathrm{SCH}$, this study employs a constructivism worldview that necessitates the adoption of the interpretative research approach and its associated qualitative research methodology. In particular, this study assumes a case study methodology to conduct the investigation in its natural setting and uses an interpretive approach in deriving the conclusions to the case 
results. Semi-structured interviews, document reviews, and observations were the means for data collection. The data obtained were then coded, analysed, and organized according to themes and sub-themes.

Yin (2009) suggests that a case study approach permits a good understanding and supplies a rich description of the phenomena under study, which is the $\mathrm{SCH}$ deployment practices and the key considerations of organisational Shariah governance for the deployment of SCH.

\section{Data Collection and Analysis}

The hotel industry was chosen as the case industry for the current study because it plays a key role in the nation's economic growth, and contributes to the aspiration of Malaysia in becoming a global Halal hub for halal products and services. Alpha Hotel is chosen as the case hotel based on its uniqueness: within the local halal hotel industry, the case hotel among others represents the nation's halal accommodation advancement in the hotel industry and is among the most shariah compliant, MS1900:2014 (formerly MS1900:2005) Shariah-based quality management systems - Requirements with guidance certified Shariah compliant hotel in Malaysia. With regards to $\mathrm{SCH}$, the case hotel is an 'initiator hotel'. This is because under voluntary basis, the hotel acts as among the first movers in the nation's hotel industry as it shifts itself from a conventional hotel by obtaining for MS1900:2005 certification in 2008 and implemented SCH practices based on its own initiative. In addition, the case hotel is among the 7-platinum category Muslim Friendly Hotels in Malaysia recognized under the MuslimFriendly Accommodation Recognition [MFAR] scheme which was implemented by the Islamic Tourism Centre (ITC) (ITC, 2021).

Access to the case hotel was obtained through direct contact between the researchers and the case hotel. The main source of data for this study was the personal interviews with the Quality \& Shariah Compliant Executive who is the expert of SCH practices at the case hotel. An extensive review of the $\mathrm{SCH}$ literature surrounding the research questions was undertaken before developing the interview questions. The interviews made use of a semi-structured approach, the structured component of which served as a guideline for consistency and crossreferencing. The interview involved asking the questions, elaborating and probing where necessary. The personal interviews were supplemented by studies and review of documentations, observations of guests' reviews, and information such as from the case hotel's website, Crescent Rating (an independent onsite audit or verification of Halal/Muslim friendly services and facilities) website and newspaper clippings. The whole data collection process involved tape recording, taking notes, collecting and viewing information as well as documents relevant to the $\mathrm{SCH}$ implementations. The scope of this study is on the SCH deployment practices within the case hotel's boundary.

For the process of qualitative data analysis, this study adopted Yin's (2009) data analytic procedure that relies on theoretical propositions. Following this, Yin's (2009) patternmatching logic is applied together with more specific analysis as recommended by Miles and Huberman (1994), Bloomberg and Volpe (2008).

\section{Result and Discussion}

\section{Background of Alpha Hotel}

Commencing operations in 2000, Alpha Hotel which is the case hotel in this study, is one of the hotels and resorts of Alpha Hotel \& Resorts, a subsidiary of Alpha Group of companies. The operations of the case hotel can be divided into two main categories namely: 1 ). Main 
Operations which comprises of six departments (which are the Front Desk, Food and Beverage [F\&B]: Kitchen, F\&B: Service, Housekeeping, Maintenance, and Security); and, 2). Supporting operations which consists of four departments (Human Resource \& Quality, Finance, Sales, and Marketing). In addition to suites that offer homely environment, function and meeting rooms, the case hotel is equipped with recreational facilities which include an outdoor swimming pool and children's pool, a children's playground, a putting green, squash courts, tennis courts, gymnasium, sauna, a jogging track, karaoke lounge and a games room.

Started off as a conventional serviced apartment hotel, Alpha Hotel shifted to become a Shariah compliant hotel by continuously enhancing its services and facilities to cater to Muslim guests. The hotel's restaurants are Halal-certified by JAKIM since 2007. The hotel's recreational facilities such as the swimming pool and sauna take into consideration the needs of Muslim guest as well. In 2008, Alpha Hotel became Malaysia's first hotel to receive the MS1900:2005 (currently MS1900:2014) Quality Management Systems-Requirements [QMS] from Islamic Perspectives. Alpha Hotel also adopted the MS1500:2009 (formerly MS1500:2004) Halal Food - Production, Handling and Storage - General Guidelines (Second Revision). MS1500:2009 prescribes the basic requirement and practical guidelines on the production, preparation, handling and storage of halal food (including nutrient supplements) (Department of Standards Malaysia, 2009).

Along the journey to be a Shariah compliant hotel, the 4-star serviced apartment hotel's effort is being recognised many times. For instance, Alpha Hotel is awarded as a Muslim-friendly rating of 7 by CrescentRating. This is the highest rating granted for hotels to certify that the hotel specialises in fulfilling Halal or Muslim-friendly requirements (CrescentRating, 2014). Recently in 2020, Alpha Hotel is among the nation's 7 platinum category Muslim Friendly Hotels (ITC, 2021). According to the Tourism, Arts and Culture Minister Datuk Seri Nancy Shukri in her speech during the launch of Muslim-Friendly Accommodation Recognition [MFAR] official logo at Movenpick Hotel and Convention Centre KLIA (Teh Athira, 2020), the platinum category hotels meet the most Shariah compliant requirements. This includes offering information on locations of mosques, Muslim-friendly tourist attractions and restaurants offering halal food and beverages provided at guest receptions counters, rooms and websites, clear display of qiblat direction as well as providing bidet, prayer mat and Quran in the rooms.

\section{SCH Practices}

The findings reveal that $\mathrm{SCH}$ practices are found in the operations involving all the hotel departments and staffs, interior and design as well as the products and services offered to the hotel guests. As affirmed by the Quality \& Shariah Compliant Executive, each department plays its role in assuring that the hotel is a Shariah Compliant Hotel. This thus supported a holistic SCH practices deployment at the case hotel. These SCH Operations, SCH Financial Management, and $\mathrm{SCH}$ Interior and Design practices and the related $\mathrm{SCH}$ initiatives are summarised by Table 3 below. 
Table 3: SCH Practices and Initiatives at Alpha Hotel

\begin{tabular}{|c|c|c|}
\hline SCH Practices & $\begin{array}{c}\text { Aspects / } \\
\text { Departments }\end{array}$ & SCH Initiatives \\
\hline \multirow[t]{5}{*}{ SCH Operations } & General Operations & $\begin{array}{l}\text { O Appointment of Quality \& Shariah Compliant } \\
\text { Executive. } \\
\text { O Approval by the Quality \& Shariah Compliant } \\
\text { Executive for each event in the hotel. } \\
\text { O Morning briefing on SC } \\
\text { O Shariah compliance [SC] inspection on } \\
\text { departments (SOPs \& practice) } \\
\text { O Internal Halal Committee [IHC]. } \\
\text { O Majority staff are Muslim. } \\
\text { O Akhlaq trained staff via Fardhu Ain classes, } \\
\text { weekly Yaasiin reciting, Quran reciting } \\
\text { classes, and Islamic team building with } \\
\text { Syariah background consultant. } \\
\text { O Staff follows Islamic staff dress code. }\end{array}$ \\
\hline & Main Operations & \\
\hline & $\begin{array}{l}\text { - Guest Receptions } \\
\text { Counters [Front } \\
\text { Desk] }\end{array}$ & $\begin{array}{l}\text { O Staff dress that properly covering the 'aurat'. } \\
\text { Islamic compliance procedure for non- } \\
\text { collected deposit. } \\
\text { O Prayer time table available. } \\
\text { O Information on Muslim-friendly tourist } \\
\text { attractions and restaurants offering halal } \\
\text { food and beverages. } \\
\text { Display guest dress code. }\end{array}$ \\
\hline & $\begin{array}{l}\text { - Food \& Beverage } \\
\text { [f\&b] kitchen and } \\
\text { f\&b service }\end{array}$ & $\begin{array}{l}\text { Department of Islamic Development Malaysia } \\
\text { [JAKIM]'s Halal certificate for all food \& } \\
\text { beverage outlets. } \\
\text { O Halal food \& beverage only, no alcohol drinks. } \\
\text { O Shariah compliance [SC] preparations of food } \\
\text { and beverages. } \\
\text { O Shariah compliance [SC] services provided by } \\
\text { the waiters and waitresses including Halal } \\
\text { room service. } \\
\text { O Halal banquets can be arranged on request. } \\
\text { O Majority of the staffs handling the food and } \\
\text { beverage kitchen and service are Muslim. }\end{array}$ \\
\hline & - Housekeeping & $\begin{array}{l}\text { O Halal cleaning supplies (eg., soap, shampoo, } \\
\text { cleaning chemicals). } \\
\text { o Shariah compliance [SC] cleaning process. } \\
\text { o Sergeant training for housekeeping staffs. } \\
\text { o Provision of Halalan \& Thoiyibban toiletries. } \\
\text { O Quran, prayer mat, female prayer dress and } \\
\text { prayer time table. } \\
\text { Inspection by Quality \& Shariah Compliant } \\
\text { Executive. }\end{array}$ \\
\hline
\end{tabular}




\begin{tabular}{|c|c|c|}
\hline & & $\begin{array}{l}\text { Non-Muslim housekeeping staffs for public } \\
\text { areas only. } \\
\text { Islamic compliance 'Lost \& Found'. }\end{array}$ \\
\hline & - Maintenance & $\begin{array}{l}\text { O Shariah compliance }[\mathrm{SC}] \text { agreement/contract } \\
\text { for outsource maintenance. }\end{array}$ \\
\hline & - Security & $\begin{array}{l}\text { Shariah compliance [SC] agreement/contract } \\
\text { for outsource security - eg., inclusion of } \\
\text { compensation calendar (takwim gantirugi). } \\
\text { Duty to protect faith \& religion, life, lineage, } \\
\text { intellect, \& property which comply with } \\
\text { Maqasid Syariah. }\end{array}$ \\
\hline & $\begin{array}{l}\text { Supporting } \\
\text { Operations }\end{array}$ & \\
\hline & - Sales & $\begin{array}{l}\text { Islamic contract. } \\
\text { Prohibition of events/functions that touch the } \\
\text { sensitivity of Islam }\end{array}$ \\
\hline & - Marketing & $\begin{array}{l}\text { O Avoidance of non-conformance Muslim faith } \\
\text { promotional activities. } \\
\text { Ethical promotional activities. }\end{array}$ \\
\hline & $\begin{array}{l}\text { - Human Resource \& } \\
\text { Quality }\end{array}$ & $\begin{array}{l}\text { O KPI (training hours) for religious events. } \\
\text { Commitment to charity/CSR activities (eg., } \\
\text { foods for front liners at hospitals, special } \\
\text { treats for orphans during Ramadhan and Eid } \\
\text { celebration, free foods for the homeless) }\end{array}$ \\
\hline $\begin{array}{l}\text { SCH Financial } \\
\text { Management }\end{array}$ & - Finance & $\begin{array}{l}\text { O Shariah compliance [SC] Agreement/Contract } \\
\text { with service providers. } \\
\text { O Shariah compliance [SC] purchasing - halal } \\
\text { certified supplier, purchase of Halal certified } \\
\text { supplies, suppliers practicing SC operations, } \\
\text { Halal/Syariah compliant inspection of } \\
\text { suppliers' operation, suppliers' workers } \\
\text { abide the SOP provided by JAKIM. } \\
\text { O All staffs to have Islamic bank accounts only. } \\
\text { o Commitment to Zakat - Management of zakat } \\
\text { deduction for staff. } \\
\text { O Shariah compliance [SC] (Takaful) insurances. } \\
\text { o No late payment to suppliers and service } \\
\text { providers (eg. Agoda) for interest avoidance. }\end{array}$ \\
\hline $\begin{array}{l}\text { SCH Design \& } \\
\text { Interior }\end{array}$ & Building \& Facilities & $\begin{array}{l}\circ \text { Located near mosque. } \\
\circ \text { Halal restaurants nearby. } \\
\circ \text { Male and female prayer room ['surau'] with } \\
\text { ablution facilities provided. } \\
\circ \text { Qiblat direction set by the Mufti of Federal } \\
\text { Territory, Malaysia in the surau, guest rooms } \\
\text { and function rooms (for Terawih and Hajat } \\
\text { prayers, Qiamullail). }\end{array}$ \\
\hline
\end{tabular}




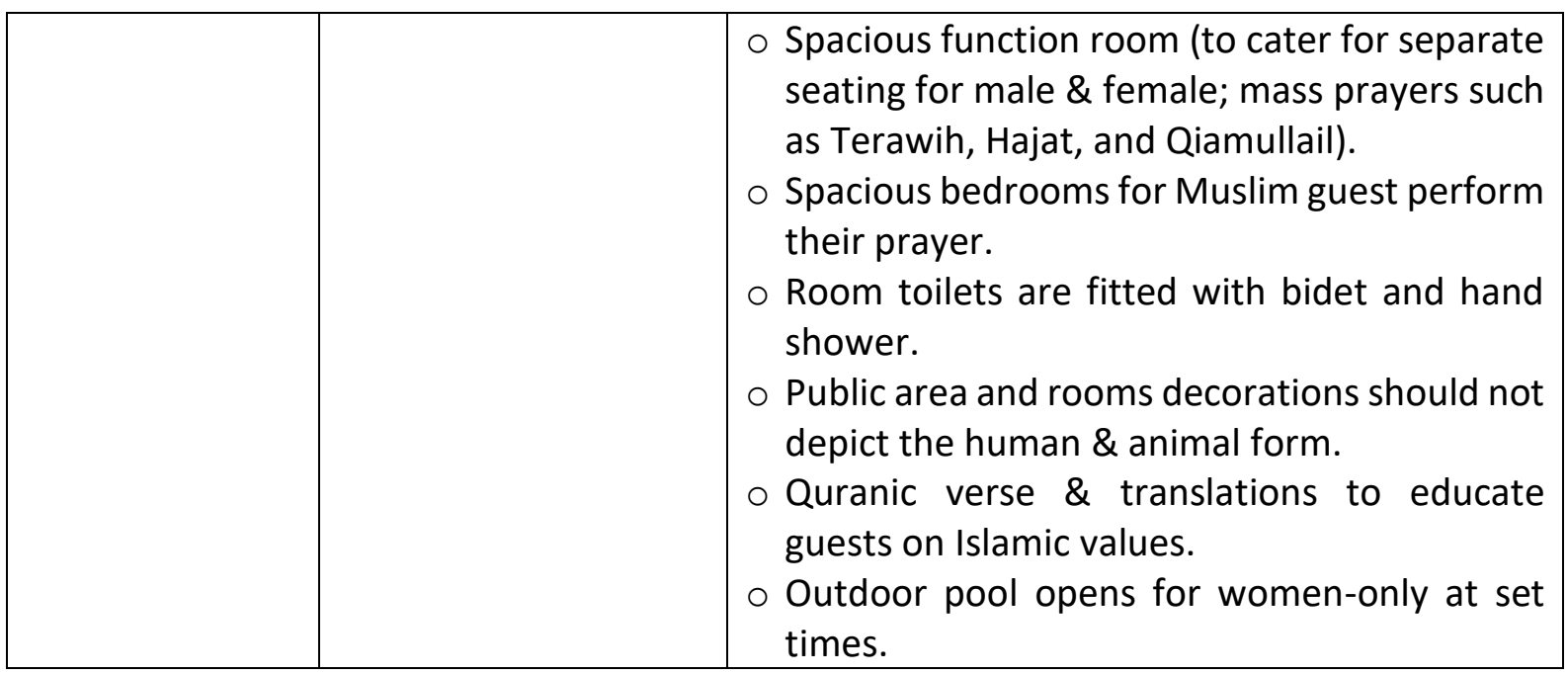

SCH Operations Practice and Initiatives

Various initiatives of SCH Operations is being deployed by the case hotel. As for the general operations, Table 3 indicated that the case hotel had appointed a Quality \& Shariah Compliant Executive who among others, is responsible in determining that all events conducted in the hotel complies to the requirements of the Shariah law. The Quality \& Shariah Compliant Executive also performed daily morning briefing to create awareness and discuss Shariah compliance [SC] related issues with the staffs. Periodic SC inspection on all departments were also conducted by the Quality \& Shariah Compliant Executive to monitor proper SC documentations and its Standard Operating Procedures [SOPs] are duly practiced. The case hotel also has an Internal Halal Committee to deliberate on SC issues in the operations of the hotel departments. Since majority of the staff are Muslim and akhlaq trained by means of Fardhu Ain classes, Quran reciting classes and Islamic team building, the SCH practices and initiatives are easier to be understood and deployed. For instance, all the staff had positively responded to the hotel's requirement in adhering to Islamic dress code.

Initiatives of $\mathrm{SCH}$ Operations practices are also found in each of the departments involved in the main as well as the supporting operations of the case hotel. For instance, with respect to the main operations, the hotel guests upon arrival are greeted by staffs of the front desk staffs who follows Islamic staff dress code. Islamic compliance procedure for non-collected deposit is also in place. Upon incidences whereby, the hotel guest checked out without collecting back the deposit put at front, the case hotel will contact the guest for at least five times. Should the guest failed to be contacted, the non-collected deposit will be handed to the Federal Territory Islamic Religious Council [MAIWP] for proper management. Prayer time table, information on Muslim-friendly tourist attractions and restaurants offering halal food and beverages as well as the guest dress code are provided at the guest receptions counters.

In addition, with regards to the case hotel's food and beverage (kitchen and service) departments, Alpha Hotel's main kitchen and its two restaurants were Halal certified by the Department of Islamic Development Malaysia [JAKIM]. The food and beverages preparations as well as the services provided by the waiters and waitresses at the restaurants, the function rooms as well as the room service are also in compliance with Shariah. Halal banquets can be arranged upon request. Majority of the staffs handling the food and beverage kitchen and service are Muslim. 
In providing shariah compliant products and services to the guest, housekeeping plays a very important role. The house keeping department does not only relies on Halal cleaning supplies such as cleaning chemicals, but also implemented Shariah compliant cleaning process. For instance, separate cleaning towels are used for cleaning the bathroom, the kitchen, and the dishes in the guest rooms. Sergeant of the kitchen, dishes and utensils are being done at certain situations and thus, the housekeeping staffs are being given sergeant trainings too. The housekeepers enter the rooms with their shoes off. The guest rooms are also supplied with 'Halalan and Thoiyibban' toiletries and provided with Quran, prayer mat as well as prayer veil. Room and housekeeping process inspections are being conducted by the Quality \& Shariah Compliant Executive. Only Muslim housekeeping staffs handles the guest rooms. Meanwhile the non-Muslims are given the housekeeping tasks for public areas only. In addition, the housekeeping department also has an Islamic compliance 'Lost \& Found' in place. In instances whereby, a hotel guest accidentally left their valuable belongings or money behind, the item will be kept in a safe place for one year. Should within that time frame the hotel guest are unable to be reached and did not come back for the item, it will be handed over to MAIWP for proper management. Non-valuable items are also treated the same. However, the holding period is only three months before the item is handed over to MAIWP.

All floors of the case hotel building are equipped with a computerized key system, closedcircuit TV surveillance cameras [CCTV] and 24 hours security. Even though these security measures are also found in conventional hotels, these initiatives are regarded as $\mathrm{SCH}$ initiatives since it upholds the duty to protect faith and religion, life, lineage, intellect, and property of which comply with Maqasid Syariah.

$\mathrm{SCH}$ practices are also found being deployed at the supporting operations department. As an example, the Human Resource \& Quality department is responsible in setting Shariah-related training hours as one of the key performance indicator [KPI] for the case hotel's staffs. Hence, the staffs are scheduled for yearly Islamic team building conducted by a Muslim facilitator with Syariah background. The Muslim staffs are also expected to participate in religious programs such as Quran and Yaasiin recital classes as well as 'zikir munajat'.

According to Islam, it is obligatory on every person including business entities who has the capacity to perform charity/socially responsible activities. Therefore, as a business entity that follows Shari ah-based principles, the case hotel should naturally practice charity/Corporate Social Responsibility [CSR]. Hence, as a commitment to charity/CSR, four programs are set annually. These programs include providing free foods for the Covid-19 front liners at hospitals, special treats for orphans during Ramadhan and Eid celebration, and free foods for the homeless.

\section{SCH Financial Management Practice and Initiatives}

The case hotel's Finance department deploys the SCH Financial Management practice. Findings of this study reveals several initiatives in relation to $\mathrm{SCH}$ Financial management practice. For instance, compensation calendar (takwim gantirugi) is included in the agreement/contract with the outsource security company. The Finance department also plays an important role in ensuring Shariah compliance [SC] purchasing. This is done by determining SC purchasing terms are stated in the purchasing of supplies and service agreements. Among others, the requirement of Halal certified suppliers, purchase of Halal certified supplies only, 
suppliers such as the outsource laundry company to practice SC operations, and the suppliers' workers to abide with the SOP provided by JAKIM. Based on these terms of agreement with the suppliers and service providers, Halal/SC inspection on the operations of the suppliers and service providers are conducted. In addition, all of the case hotel's staff are required to open an Islamic bank account for their payroll. As a commitment to zakat (alms), the case hotel promotes and assists in the management of zakat deduction from the staffs' salary. The case hotel also only purchases SC insurances for the hotel building and staffs. Since interest is prohibited in Islam, efforts for interest avoidance is implemented. The Finance department monitors and manages payment to the suppliers and service providers such as AGODA to avoid any late payments and the resultant interest charges.

\section{SCH Design \& Interior Practice and Initiatives}

The design and interior of the case hotel also support and uphold the requirements of Shariah. The case hotel is located halal restaurants thus providing choices of food outlets to the Muslim guests. Even though located near mosque, the case hotel does provide for male and female prayer room ['surau'] with ablution facilities. Qiblat direction which is set by the Mufti of Federal Territory, Malaysia is available in the prayer room, all the guest rooms and the function rooms. In addition, the function rooms are spacious to cater for separate seating for male and female guests as well as for mass prayers such as Terawih, Hajat, and Qiamullail performed by groups of hotel guests who booked the function rooms for their events.

The case hotel's guest rooms are made as Shariah compliant as possible. The rooms are spacious for Muslim guest to perform their prayer. The toilets in the guest rooms are fitted with bidet and hand shower too. Similar to the case hotel's public areas, the guest rooms decorations do not depict human and animal forms. Instead, Quranic verse and translations are displayed to educate the case hotel's guests on Islamic values. In addition, the outdoor pool is open for women-only at set times to promote SC recreational activities.

\section{Key Elements of Organisational Shariah Governance for SCH Deployment}

Consistent with extant governance literature, the case findings reveal that an appropriate organisational governance framework are essential for the deployment of SCH practices at the case hotel. From the case evidence it is noted that five business considerations components are found at Alpha Hotel namely: 1) $\mathrm{SCH}$ principle/value; 2) $\mathrm{SCH}$ policy; 3) $\mathrm{SCH}$ process; 4) SCH performance measurement system [PMS]; and, 5) SCH people/oversight.

\section{SCH Principle / Value}

According to extant literature (e.g., Zaphiris, 2006; Environment Agency, 2004), a firm's principle is usually embedded in the corporate texts such as the statements of vision, mission, values, and policies. Likewise, the case findings indicate that $\mathrm{SCH}$ principle is embedded in the case hotel's vision statement and core values. The case hotel's vision statement is:

“...to be the preferred hotel and suites in accordance to Shariah requirements."

In its strive towards being the preferred hotel and suites among travellers and tourists, Alpha Hotel finds it necessary to abide to Shariah requirements. By including Shariah compliance in the formulation of its vision statement, Alpha Hotel has clearly identified $\mathrm{SCH}$ principle/value 
as one of its core business values. As a core component for organisational Shariah governance, it spells out the case hotel's commitment towards Shariah compliance.

The case hotel's corporate mission is further emphasized in its core values. The core values focus on four key areas which are: 1) Trustworthy [Sidiq]; 2) Integrity [Amanah]; 3) Communication [Tabligh]; and, 4) Knowledge [Fatanah]. According to the Quality \& Shariah Compliant Executive, the vision statement is being disseminated to all the workforce and the core values are embedded throughout the case hotel's business processes. The core values are subsequently internalised as being the case hotel's work culture. For instance, the four core values are highlighted during morning briefings. In addition, both the vision statement and the core values are printed in the form of pocket note and leaflets and are made available to the case hotel's personnel and external parties. Memos on the core values are also pinned at each departments' notice board.

The case findings indicate a link between $\mathrm{SCH}$ principle/value and the remaining organisational shariah governance components. According to the Quality \& Shariah Compliant Executive who is the case hotel's SCH champion, the $\mathrm{SCH}$ principle/value at Alpha Hotel is supported by the development of clear $\mathrm{SCH}$ policy, $\mathrm{SCH}$ process, SCH PMS as well as strong SCH people/oversight.

\section{SCH Policy}

The case evidence highlighted that Alpha Hotel's Quality policy focuses on both quality and Shariah compliance. The Quality policy quotes the case hotel as "...a premier accommodation provider committed to:

i) Excel in delivering quality services,

ii) Achieve competitive returns,

iii) Commitment to satisfy applicable requirements, and

iv) Striving for continuous improvement through a proficient and dedicated team in accordance with Shariah requirements."

The first three policy statement of the case hotel relates to delivering quality services, achieving competitive returns, and meeting related requirements. However, the fourth policy statement underlines compliance to Shariah in achieving continuous improvement of quality by all personnel in all the departments functioning as a team within the case hotel. This thus suggests for a holistic Shariah compliance at the case hotel. In addition, to execute the Quality (and SCH) policy, the case hotel adopts and is MS1900:2014 certified. As asserted by the Quality \& Shariah Compliant Executive of the case hotel, compliance to Shariah requirements supports the case hotel's strive for quality in materialising its vision statement as earlier discussed (see 4.3.1 SCH principle/value).

According to the Quality \& Shariah Compliant Executive of the case hotel, the development of the Quality (and SCH) policy comes at the early stage of the MS1900:2005 (currently MS1900:2014) implementation. The Quality \& Shariah Compliant Executive further added that the Quality (and $\mathrm{SCH}$ ) policy sets the direction for the $\mathrm{SCH}$ deployment process. 


\section{SCH Process}

The $\mathrm{SCH}$ process is another key business consideration supporting the execution of the case hotel's SCH principle/value statement. In 2008, Alpha Hotel which initially operated as a conventional hotel had shifted to become a Shariah Compliant Hotel by adopting the MS9001:2005 (currently MS1900:2014) Quality Management Systems - Requirements from Islamic Perspective. Consistent with prior researches (Abd Razak et al., 2019; Sahida et al., 2011), the findings indicate that the implementation of the Islamic Quality Management System MS1900 resulted in a holistic deployment of SCH practices in the case hotel. As commented by the Quality \& Shariah Compliant Executive:

".. the implementation of MS1900 is holistic. It covers everything from the first process to the end process of each department in the case hotel...."

This is evidenced by the deployment of $\mathrm{SCH}$ practices and initiatives in a holistic manner, rather than in an unsystematic, piecemeal approach as earlier discussed (see $4.2 \mathrm{SCH}$ Practices). In addition, within the framework built on Deming's Plan-Do-Check-Act [PDCA] continuous improvement model, the MS1900 permits Alpha Hotel to continuously and systematically address $\mathrm{SCH}$ and to mitigate any non-compliance with Shariah particularly within the case hotel's operations. As affirmed by the Quality \& Shariah Compliant Executive, in the implementation of MS1900, every flow in each of the processes will be closely inspected and monitored to ensure compliance to Shariah requirements. Should there is any non-compliance with the Shariah requirements, corrective actions or rectification to overcome the situation is made. Preventive actions are also implemented to eliminate causes of potential non-conformities thus preventing any re-occurrences.

The Quality \& Shariah Compliant Executive also asserts that with the implementation of MS1900, the case hotel is able to be operationalised and managed in compliance with the principles of Shariah and practice of the quality management system in delivering products and services that meet the guests' requirements. The Quality \& Shariah Compliant Executive added that to date, the case hotel has not received any major complaints which relates to Shariah from the guests.

The SCH Process implementation of MS1900 calls for the development of appropriate SCH PMS and this is discussed in the next section.

\section{SCH Performance Measurement System [PMS]}

The case hotel's Quality (and SCH) policy (see 4.3.2 SCH Policy) amongst others states that it is the policy of Alpha Hotel to: "... TO SATISFY" (that denotes COMPLY WITH) "applicable requirements" and "STRIVING FOR CONTINUOUS IMPROVEMENT through a proficient and dedicated team in accordance with Shariah requirements". As suggested by the literature (e.g., Jasch, 2000), the words 'compliance' and 'continual improvement' suggested the need for performance measurement.

At Alpha Hotel, the $\mathrm{SCH}$ process, while contributing to $\mathrm{SCH}$ principle/value, has also supported the accomplishment of SCH policy and promoted the development of SCH PMS. The SCH PMS serves as a monitoring and tracking mechanism for the case hotel's SCH performance. Along this line of discussion, the Quality \& Shariah Compliant Executive of Alpha Hotel highlighted 
that Shariah compliant monitoring and measurement is conducted to reflect the MS1900 / system performance. He further explains that 4 key $\mathrm{SCH}$ performance areas for a comprehensive SCH performance at Alpha Hotel: 1) customer complaints/satisfaction; 2) applicable legal/requirements compliance; 3) CPAR [Corrective Preventive Action Request] or NCR [Non-conformance]; and, 4) Objectives \& Targets achievement:

"...my system performance, I would look at: 1) customer complaints-guests comments, to assess customer satisfaction.; 2) my applicable legal/requirements compliance-such as JAKIM's regulations, the muftis' 'fatwa'; 3) my CPAR [Corrective Preventive Action Request] or NCR [Non-conformance - this is internal audit; 4) my O\&T achievement I have to look at how many O\&T on processes \& product for that year, and how many that I have achieved. From these, I will see \& I can conclude - on how my system performance is, overall ...".

Besides the SCH policy and the MS1900 related SCH process, a comprehensive SCH PMS is an important mechanism for developing, monitoring and tracking of the case hotel's Shariah compliance performance.

The top management of Alpha Hotel will periodically review the MS1900 system of the hotel during the Management Review Meeting [MRM] conducted. With the aim to ensure the system's continuing suitability, adequacy, and effectiveness, all aspects of the MS1900 system of the case hotel will be reviewed and deliberated. Among others are the key SCH performance areas including the KPIs of all departments and guests' feedbacks, the continuous improvement efforts implemented, the moving forward plan, and changes in the documentations. The management review thus provides a closure point for the implementation of the PDCA-MS 1900 at Alpha Hotel. It also serves the oversight which is an important support mechanism for the deployment of $\mathrm{SCH}$ at the case hotel.

\section{SCH People/Oversight}

The literature (e.g., Khairani, 2015; Luo, 2005) suggests that both board and managerial level oversight are important to ensure that $\mathrm{SCH}$ policy, process and PMS support the $\mathrm{SCH}$ principle. Along this line of argument, the Quality \& Shariah Compliant Executive of Alpha Hotel agrees that oversight at both the Board and the Senior management \& working levels is important for organisational Shariah governance. Diagram 1 depicts the organisational Shariah governance chart of Alpha Hotel. 


\section{Diagram 1: The Organisational Shariah Governance Chart of Alpha Hotel.}
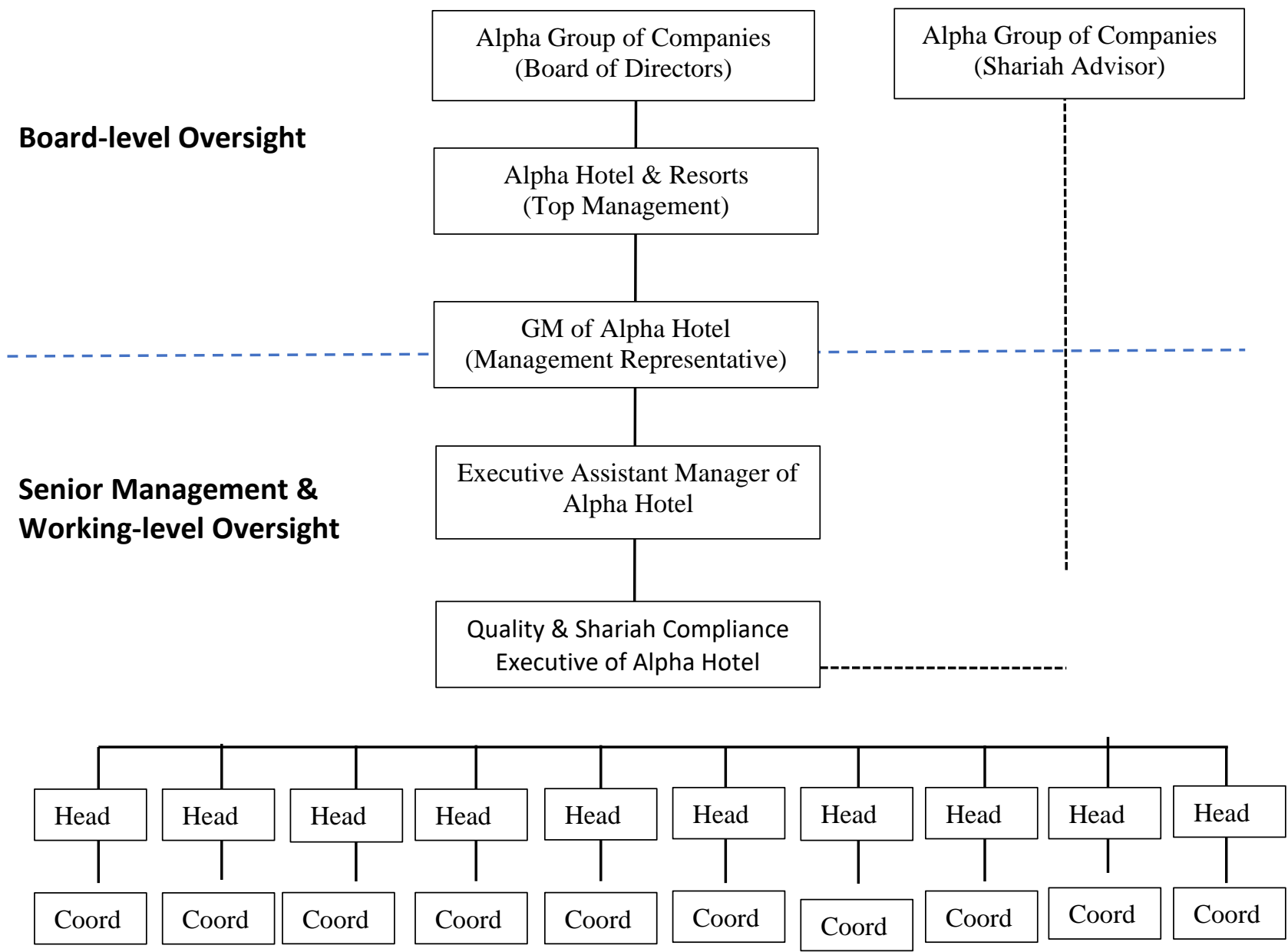

As shown in Diagram 1, the involvement of the people in Alpha Hotel at the Board level as well the Senior management \& working levels were evident. The case evidence also reveals that the implementation of the MS1900 - SCH Process calls for a good SCH oversight both at the Board level and the Senior management and working level.

Board-level Oversight

At the Board-level, a Shariah Advisor as shown in Diagram 1 is appointed to act as the reference centre on Islamic management issues of the Alpha Group of Companies. The appointed Shariah Advisor is responsible to review, advice and endorse the management of the Shariah matters of Alpha Group of Companies including of Alpha Hotel.

As depicted in Diagram 1, the General Manager [GM] of Alpha Hotel acts as the Management Representative at the top management level of Alpha Hotel \& Resorts. Shariah-related concerns will be brought to the attention of the Management Representative. Should there is any unsolved Shariah-related issues, it can be forwarded directly to the Shariah Advisor. Alternatively, any MS1900 related concerns will be forwarded to the Business Process Compliance Unit at the top management level and where necessary, will be forwarded to the Shariah Advisor and/or to the Board of Directors, Alpha Group of Hotels. Any Shariah-related approvals made by the Shariah Advisor will be brought to the Board's attention during the Board meeting held each quarter of the year. 


\section{Senior Management \& Working-level Oversight}

For excellent SCH deployment, Alpha Hotel has in place a hotel-wide Internal Halal Committee (IHC) to spearhead and anchor the $\mathrm{SCH}$ at the case hotel. As shown in Diagram 1, the IHC organizational structure clearly identifies key personnel for the Alpha Hotel's hotel-wide SCH: General Manager [GM]; Executive Assistant Manager; Quality \& Shariah Compliant Executive; Head of Departments [HODs] who are the departments' managers/assistant managers; and $\mathrm{SCH}$ Coordinators of each departments. The IHC involves recruitment of hotel-wide senior management and working-level representatives as the team members (Diagram 1). This structure reflects a strong managerial/senior management and working level oversight mechanism, which in turn ensuring continuous improvement in the management of $\mathrm{SCH}$ at Alpha Hotel.

IHC among others deliberates on the Shariah-related matters in the daily operations and activities of the case firm's departments. For instance, the IHC will decide on the selection and appointment of suppliers by reviewing among others its Shariah compliance criteria. Except for the SCH Coordinators, IHC members are involved in the Management Review Meeting [MRM] conducted annually. During the MRM, the GM and members review the case hotel's MS1900 system (see 4.3.4 SCH Performance Measurement System [PMS]). As the Management Representative, the GM will then forward the report as well as any Shariahrelated issues to the attention of the top management (see 4.3.5.1 Board-level oversight).

Within the Senior management \& working-level oversight, the Quality \& Shariah Compliant Executive plays an important role in $\mathrm{SCH}$ deployment at the case hotel. As the $\mathrm{SCH}$ champion, the Quality \& Shariah Compliant Executive among others is responsible to ensure continuous compliance of Shariah requirements and to monitor its implementation in the daily operations of Alpha Hotel. The Quality \& Shariah Executive also is responsible to report directly to the top management and indirectly to the Shariah Advisor on Shariah matters, including Shariah non-compliance, if any.

\section{Conclusions, Contributions, Limitations and Suggestions for Future Research}

The case findings confirm that the procedure-led MS1900:2014 (formerly MS1900:2005) Shariah-based quality management systems - Requirements with guidance supports the integration of $\mathrm{SCH}$ practices within the operational activities of the case hotel. Consistent with proponents of SCH (e.g., Sahida et al., 2011) the case evidence also suggests that the case hotel which adopted MS1900 have deployed SCH in a holistic manner, rather than in an unsystematic, piecemeal approach. SCH Operations, SCH Financial Management, and SCH Interior and Design practices and the related $\mathrm{SCH}$ initiatives are found in the operations involving all the hotel departments and staffs, interior and design as well as the products and services offered to the hotel guests.

Good corporate governance is prerequisite in the implementation of an effective quality management system. The above discussion highlighted $\mathrm{SCH}$ principle/value, $\mathrm{SCH}$ policy, $\mathrm{SCH}$ process, SCH PMS, and SCH people/oversight are the elements of organisational Shariah governance at the case hotel. SCH principle/value is supported through the implementation SCH policy, SCH process, and SCH PMS. The above discussion also suggested the need for SCH people/oversight for effective organisational Shariah governance. In addition, the implementation of MS1900:2014 (formerly MS9001:2005) Quality Management Systems - 
Requirements from Islamic Perspective necessitates the development of appropriate $\mathrm{SCH}$ principle/value, SCH policy, SCH process, SCH PMS, and SCH people/oversight. Hence, by virtue of implementing the MS1900:2014 (formerly MS9001:2005), the case hotel is able to put in place as the key elements of organisational Shariah governance which directly supports the deployment of $\mathrm{SCH}$.

By adopting a case study approach, the current study contributes to the body of literature in providing insights about $\mathrm{SCH}$ deployment particularly on the organizational Shariah governance that might not be evident otherwise of a relatively new phenomenon, like $\mathrm{SCH}$. This study is not without limitations. This investigation and its findings are still relatively exploratory, focusing on the SCH deployment by a Shariah compliant hotel within the Malaysian hotel industry. The findings are not conclusive due to a single case firm selected for the Shariah compliant hotels operating in Malaysia. Opportunities for future research arise from the findings of this study. A multiple case study within the industry in Malaysia may provide a better picture of the local SCH experience.

\section{References}

Abd Razak, N. A., Yusof, R. N., \& Ab Aziz, Y. (2019). Challenges in implementing Muslim Friendly Hospitality Services (MFHS) in Shariah-compliant hotels in Malaysia. International Journal of Academic Research in Business \& Social Sciences, 9(10), 97-104.

Abdul Majid, N. H., Denan, Z., Abdullah, F. H., \& Noor, M. S. (2015). Shariah compliance hospitality building design: A Malay Muslim oriented culture. Procedia-Social and Behavioral Sciences, 201, 136-145.

Abu Karim, M. H., Ahmad, R., \& Zainol, N. A. (2017). Differences in hotel attributes: Islamic Hotel and Sharia Compliant Hotel in Malaysia. Journal of Global Business and Social Entreprenurship, 1(2), 157-169.

Nordin, A. N. S., \& Abd Rahman, F. (2018). A critical review of the Muslim-friendly hospitality services standard (MS 2610:2015) in Malaysia. Proceedings of the $3^{\text {rd }}$ International Halal Conference (INHAC 2016), pp.211-222.

Bernama. (2021). Malaysia's domestic tourism posts highest growth in ASEAN in $2 \mathrm{H} 2020-$ Agoda. The Edge Markets, July 9, https://www.theedgemarkets.com.

Bloomberg, L. D., \& Volpe, M. (2008). Completing your qualitative dissertation: A roadmap from beginning to end. California, USA, SAGE Publications.

Carnegie Mellon University (2003). Values and cultures. Retrieved April 7, 2010, from telstar.ote.cmu.edu

Che Ahmat, N., Ridzuan, A. H., Din, N., Zainol, N., \& Razali, M. A. (2015). Syariah Compliant Hotel: The concepts \& practices. Journal of Tourism, Hospitality \& Culinary Arts, 7(2), 52-66.

Che Omar, C. M., \& Adaha, M. A. N. (2019). An operational Shariah Compliant Hotel requirements: Malaysia experience. Journal of Hospitality \& Networks, 1, 23-33.

Crescentrating. (2014). PNB Perdana Hotel \& Suites on The Park Awarded Highest MuslimFriendly Rating by CrescentRating. https://www.crescentrating.com

Department of Standards Malaysia. (2015). MS 1900:2014 Shariah-based quality management systems-Requirements with guidance (first revision). Cyberjaya: Department of Standards Malaysia. http://www.standardsmalaysia.gov.my

Department of Standards Malaysia. (2014). MS 2610:2015 Muslim friendly hospitality services - Requirements. Cyberjaya: Department of Standards Malaysia. 
http://www.standardsmalaysia.gov.my

Department of Standards Malaysia. (2009). MS1500:2009 Halal Food-Production, Handling and Storage - General Guidelines (Second Revision). Cyberjaya: Department of Standards Malaysia. http://www.standardsmalaysia.gov.my

El-Gohary, H. (2020). Coronavirus and Halal tourism and Hospitality industry: Is it a journey to the unknown? Sustainability, 12(21), https://doi.org/10.3390/su12219260.

El-Gohary, H. (2015). Halal tourism, is it really Halal? Tourism Management Perspectives, http://dx.doi.org/10.1016/j.tmp.2015.12.013.

Environment Agency. (2004). Corporate environmental governance: A study into the influence of environmental governance and financial performance full report. retrieved April 12, 2009, from www.environment-agency.gov.uk.

Hoong, C. Y. (2021). Cover story: Hospitality industry prepares for recovery. The Edge Malaysia, April 6, https://www.theedgemarkets.com.

Islamic Tourism Centre (ITC). (2021). Islam in Malaysia. https://itc.gov.my.

Islamic Tourism Centre (ITC). (2021). Muslim Friendly Hotels (Platinum). https://itc.gov.my

Jasch, C. (2000). Environmental performance evaluation and indicators. Journal of Cleaner Production, 8, 79-88.

Khairani, N. S. (2015). Green Supply Chain Management: An advanced Corporate Environmental Governance practice in an automotive case firm (Unpublished doctoral dissertation). Universiti Teknologi MARA, Malaysia.

Luo, Y. (2005). Corporate governance and accountability in multinational enterprise: Concepts and agenda. Journal of International Management, 11, 1-18.

Salleh, M. N. Z., Abdul Hamid, A. B., Hashim, N. H., \& Omain, S. Z. (2014). The practice of Shariah-Compliant Hotel in Malaysia. International Journal of trade, Economics \& Finance, 5(1), 26-30.

Miles, M. B., \& Huberman, A. M. (1994). An expanded sourcebook: Qualitative data analysis ( $2^{\text {nd }}$ ed.), California, USA: SAGE Publications.

Ali, M. H., Basir, S. A., \& Ahmadun, M. (2016). Implementation of the Islamic Quality Management System MS1900 and its benefits: A case study at the Department of Hajj., Waqf \& Zakah, Malaysia. GJAT, 6(2), 82-98.

Yusof, M. F., \& Muhammad, M. Z. (2013). Introducing Shariah Compliant Hotels as a new tourism product: The case of Malaysia. Entrepreneurship Vision 2020: Innovation, Development Sustainability, and Economic Growth, 1 \& 2, 1142-1146.

Muhammad, Z. (2009). Al Jawhara: Promoting Islamic hospitality and Halal tourism. The Halal Journal, (May/June) 60.

Musa, A., Abdul Kadir, S., Ibrahim, M., Jusoh, N., Che Tahrim, S. N., \& Mohd Din, N. (2017). Developing a proper framework towards Shariah-Compliant Hotel in Malaysia: Identifying opportunities \& challenges. Journal of Global Business \& Social Entreprenurship (GBSE), 1(4), 103-111.

Rokeach, M. (1973). The nature of human values. The Free Press, New York, NY.

Sahida, W., Ab Rahman, S., Awang, K., \& Che Man, Y. (2011). The implementation of Shariah Compliance concept hotel: De Palma Hotel Ampang, Malaysia. $2^{\text {nd }}$ International Conference on Humanities, Historical \& Social Sciences IPEDR, 17, 138-142.

Samori, Z., Abd Rahman, F., \& Zahari, M. S. (2017). Conceptual framework for Shari'ah Governance with special reference to the Muslim Friendly Hotel sector in Malaysia. In M.H. Bilgin et al. (eds.), Country Experiences in Economic Development, Management 
\& Entrepreneurship, Eurasian Studies in Business \& Economics, Springer International Publishing, 717-731.

Shankar, A. C. (2021). With international travel cut off, industry sees domestic tourism as lifeline and route to recovery. The Edge Markets, March 11, https://www.theedgemarkets.com.

Teh Athira, Y. (2020). 42 hotels recognised as syariah-compliant to attract more Muslim tourists. New Straits Times, September 3, https://www.nst.com.my.

Tourism Malaysia (2020). Malaysia's tourism performance records negative growth of $78.6 \%$ from Jan-Sep 2020. https://www.tourism.gov.my

Vasantha, G. (2021). Surviving the impact of Covid-19: Tourism industry waits to cruise out of the doldrums. The Edge Malaysia, January 11, https://www.theedgemarkets.com.

Yin, R. K. (2009). Case study research: Design and methods (4 ${ }^{\text {th }}$ ed.). California, USA: SAGE Publications.

Zaphiris, A. (2006). A semantic network analysis of global corporate values statements. The State University of New York, Buffalo. 